\title{
CHALLENGE OF GERONTOLOGICAL TRAINING IN BRAZIL
}

\section{O desafio da formação gerontológica no Brasil}

The increase in life expectancy requires advances in all spheres of care for aging individuals, with the aim of producing positive impacts and adding quality to the years gained. Therefore, there is an urgent need to train qualified professionals to meet the demands of this rapidly growing group. ${ }^{1}$

In view of the poor distribution and the lack of properly qualified human resources, it is important to reflect on the educational processes and on the competencies that are within the scope of such professionals. ${ }^{2}$

In Brazil, gerontological training follows diversified paths, thus lacking a stronger rationale and a more consistent debate. By analyzing the history of gerontological training, we may infer that it has developed circumstantially, according to the increase in the aging population.

In the 1960s, after the demographic transition became more expressive, the Brazilian Society of Geriatrics and Gerontology (Sociedade Brasileira de Geriatria e Gerontologia, SBGG) pioneered the training of interested professionals, even before academic spaces addressed the discussion on aging.

Almost 30 years later, the National Policy for Older Persons, ${ }^{3}$ introduced in 1994, recommended in one of its articles the inclusion of courses on geriatrics and gerontology at the undergraduate level. This action has advanced slowly and almost unwillingly. Few undergraduate programs have adopted such recommendation, and those that have done it include gerontology only as an elective course.

From the 1990s onwards, there has been an increasing number of graduate programs in aging and related areas. Despite that being an advance, the curriculum, the profile of the professional who is qualified to be in the faculty of the several existing programs, and the elective courses of the undergraduate programs of the various professional categories have not been standardized.

In 2005, the first undergraduate programs in gerontology were created in Brazil, but they still lacked robustness because of the slow pace of the Brazilian Congress, which halted the bill for regulation of the bachelor's degree in gerontology, whose initial procedures date back to 2013. For a long time, the existence of such undergraduate programs has triggered controversial debates, but in an isolated and unfounded manner; however, there is no doubt that consistent reflections and debates are essential for listing the required competencies at the undergraduate level.

In addition to training, the title of specialist holds a significant place. For years, it was up to SBGG, after a thorough evaluation of the candidate's professional career, to confer the title of specialist in gerontology to those who undergo the examination.

In recent years, given the invisibility of the professional working in the field of aging and the low value attributed to this title, SBGG has formed partnerships with professional boards and associations to make gerontology recognized as an important field of expertise in the life cycle. Furthermore, in an attempt to achieve the consistency that legitimizes the identity of the specialist, there is an effort to provide certification together with professional associations, as is the case with the Brazilian Medical Association for conferring the title of geriatric specialist.

Most likely, the invisibility of the gerontology specialist is due to the lack of understanding about what gerontological training means, given that this topic has not been included in the agenda of the professional training and qualification institutions.

To strengthen the identity of the gerontology specialist, it is essential to be open to discussion and willing to work together at all levels of professional training and qualification. 
Finally, we invite readers to make a critical analysis of daily praxis and their training process, as well as of the barriers that need to be overcome, so that gerontology specialists achieve visibility and legitimacy.
Maria Angélica dos Santos Sanchez Collaborating researcher at the Human Aging Research Laboratory, Universidade do Estado do Rio de Janeiro - Rio de Janeiro (RJ), Brazil.

\section{REFERENCES}

1. Organização Pan-americana da Saúde (OPAS). Folha informativa: envelhecimento e saúde. OPAS; 2018. Available at: https://www. paho.org/bra/index.php?option=com_content $\&$ view $=$ article $\& i d=56$ 61:folha-informativa-envelhecimento-e-saude\&ltemid=820. Access on Dec. 7, 2020.
2. Crisp N, Chen L. Global Supply of Health Professionals. N Engl J Med. 2014;370(10):950-7. https://doi.org/10.1056/NEJMra1111610

3. Brasil. Lei no 8.842, de 4 de janeiro 1996. Dispõe sobre a Política Nacional do Idoso, cria o Conselho Nacional do Idoso e dá outras providências. Brasil; 1996. 